\title{
PENGEMBANGAN MEDIA LUDO MATH PADA MATERI PECAHAN SEDERHANA BAGI PESERTA DIDIK KELAS III SEKOLAH DASAR
}

\author{
Alfiatun Nur Azizah dan Meita Fitrianawati
}

Universitas Ahmad Dahlan Yogyakarta

E-mail: alfiaazizah1@gmail.com

\section{Info Artikel}

SejarahArtikel:

Diserahkan 15 April 2020

Direvisi 23 Juni

Disetujui 23 Juni 2020

\section{Keywords:}

ludo math media,

simple fractions,

elementary school.

\begin{abstract}
This research aims to determine the steps of media development and to know the quality and feasibility of Ludo Math media.The Ludo Math media was developed with a Borg and Gall model consisting of; 1) research and information collecting, 2) planning, 3) develop preliminary form of product, 4) preliminary field testing, 5) main product revision, 6) main field testing, 7) operational product revision, and 8) operational field testing.

The study was conducted at SD NegeriGetas 02 with the subject students training class III. Data collection techniques in the form of observation, interviews, assessment sheets of experts and teachers, and student response sheets.Analysis of the data of this study includes qualitative data analysis and quantitative data analysis.

The results of this study indicate that the assessment according to media experts obtained a value of 85 with the category "Very Good". Assessment according to learning experts obtained a value of 92.5 with the category "Very Good". The assessment according to the material experts obtained a value of 87.5 with the category "Very Good". Small Group Product Trial Results, teacher assessment and student responses obtained an average value of 96.25 with the category "Very Good". The results of the Large Group Usage Trial, the assessment of teachers and students obtained an average value of 98.75 in the "Very Good" category. From all assessments of experts, teachers, and students, Ludo Math media get an average value of 92. If the average value is converted into qualitative data, Ludo Math media is included in the "Very Good" category and declared fit for use in the material Simple fractions class III elementary school.
\end{abstract}

\begin{abstract}
Abstrak
Penelitian pengembangan ini bertujuan untuk mengetahui langkah-langkah pengembangan media dan mengetahui kualitas serta kelayakan media Ludo Math. Media Ludo Math ini dikembangkan dengan model Borg and Gall yang terdiri dari; 1) research and information collecting, 2) planning, 3) develop preliminary form of product, 4) preliminary field testing, 5) main product revision, 6) main field testing, 7) operational product revision, and 8) operational field testing.

Penelitian dilaksanakan di SD Negeri Getas 02 dengan subyek uji coba peserta didik kelas III. Teknik pengumpulan data berupa observasi, wawancara, lembar penilaian para ahli dan guru, serta lembar respon peserta didik. Analisis data penelitian ini meliputi analisis data kualitatif dan analisis data kuantitatif.

Hasil penelitian ini menunjukan penilaian menurut ahli media diperoleh nilai 85 dengan kategori "Sangat Baik". Penilaian menurut ahli pembelajaran diperoleh nilai 92,5 dengan kategori "Sangat Baik". Penilaian menurut ahli materi diperoleh nilai 87,5 dengan kategori "Sangat Baik". Hasil Uji Coba Produk Kelompok Kecil, penilaian guru dan respon peserta didik diperoleh nilai rata-rata 96,25 dengan kategori "Sangat Baik". Hasil Uji Coba Pemakaian Kelompok Besar, penilaian guru dan peserta didik diperoleh nilai rata-rata 98,75 dengan kategori "Sangat Baik". Dari seluruh penilaian para ahli, guru, dan peserta didik, media Ludo Math mendapatkan nilai rata-rata 92. Apabila nilai rata-rata dikonversikan ke dalam data kualitatif maka media Ludo Math termasuk dalam kategori "Sangat Baik" dan dinyatakan layak untuk digunakan pada materi Pecahan Sederhana kelas III SD.
\end{abstract}

(C) 2020 Universitas Muria Kudus 


\section{Alfiatun Nur 'Azizah dan Meita Fitrianawati \\ PENGEMBANGAN MEDIA LUDO MATHPADA MATERI PECAHAN SEDERHANA .. WASIS: Jurnal Ilmiah Pendidikan. Volume 1, Nomor 1, hlm. 28-35}

\section{PENDAHULUAN}

Sistem pendidikan di Indonesia terdapat perubahan dalam bidang pendidikan yang mengubah sudut pandang mengenai sistem pembelajaran yang dulunya konvensional menjadi sistem pembelajaran modern. Fitrianawati (2017) berpendapat bahwa peran utama dalam mewujudkan pendidikan yang berkualitas adalah dengan adanya kurikulum, sehingga jika dalam penyusunan kurikulum terjadi kegagalan, maka tujuan dari pendidikan tidak akan terwujud. Berlakunya Kurikulum 2013 di SD/MI maka setiap proses pembelajaran pada satuan pendidikan diselenggarakan secara interaktif, inspiratif, menyenangkan, menantang, memotivasi peserta didik untuk berpartisipasi aktif, serta melakukan ruang yang cukup bagi prakarsa, kreativitas, dan kemandirian sesuai dengan bakat, minat, dan perkembangan fisik serta psikologi peserta didik.

Salah satu disiplin ilmu yang dipelajari oleh peserta didik dari tingkat dasar sampai jenjang tinggi adalah pelajaran matematika. Matematika merupakan suatu cabang ilmu yang berkaitan dengan kehidupan sehari-hari yang identik dengan angka, bilangan, nilai, rumus, bangun ruang, operasi hitung, dan lainlain. Matematika merupakan salah satu bidang studi yang mendukung perkembangan ilmu pengetahuan dan teknologi. Jhonson dan Myklebust (Sundayana, 2016) mengemukakan bahwa matematika merupakan bahasa simbolis yang memiliki fungsi praktis untuk mengekspresikan hubungan-hubungan kuantitatif dan keruangan.

Mardati (2016) mengemukakan bahwa matematika merupakan ilmu dasar berhitung bagi peserta didik Sekolah Dasar. Mata pelajaran matematika diberikan kepada peserta didik mulai dari tingkat SD untuk membekali mereka dalam memiliki kemampuan berpikir logis, analitis, sistematis, kritis, dan kreatif, serta kemampuan bekerjasama (Saputro, 2018: 53). Oleh karena itu, diharapkan setiap satuan pendidikan melakukan perencanaan pembelajaran, pelaksanaan proses pembelajaran serta penilaian proses pembelajaran untuk meningkatkan efisiensi dan efektifitas ketercapaian kompetensi lulusan (Permendikbud, 2016).

Keberhasilan suatu pembelajaran matematika dipengaruhi oleh penguasaan konsep dasar matematika yang ditempuh melalui suatu pembelajaran matematika (Saputro, 2018). Dalam implementasi pembelajaran matematika saat ini masih minim akan ketersediaan media pembelajaran terutama pada materi pecahan sederhana sehingga pembelajaran matematika masih dilakukan dengan metode konvensional. Menurut Priatna dan Ricki (2019) mengemukakan bahwa dengan menekankan penalaran pada mata pelajaran matematika, maka dapat mengembangkan pola pikir menjadi lebih kritis, logis, kreatif, dan sistematis sehingga matematika dijadikan tolak ukur utama untuk mengetahui kecerdasan seseorang.

Era globalisasi pada saat ini pengembangan teknologi semakin pesat sehingga berangsur-angsur mengubah segala aspek kehidupan. Pembelajaran yang berpusat pada guru sudah berubah menjadi pembelajaran yang berpusat pada peserta didik. Peserta didik dibebaskan dalam memperoleh sumber informasi atau bahan ajar tentang materi yang dipelajarinya. Menurut Sundayana (2016) kata media berasal dari bahasa Latin dan merupakan bentuk jamak dari kata medium yang secara harfiah berarti "perantara" atau "penyalur". Gagne dan Brigss (Sundayana, 2016) secara implisit menyatakan bahwa media pembelajaran meliputi alat yang secara fisik digunakan untuk menyampaikan isi materi pengajaran yang antara lain buku, tape-recorder, kaset, video kamera, film, slide (gambar bingkai), foto, gambar, grafik, televisi, dan komputer.

Pemilihan media pembelajaran harus memperhatikan kelasifikasi media pembelajaran yang baik. Adapun klasifikasi media pembelajaran yang baik menurut Sudjana dan Rivai (2010) sebagai berikut: 1) ketepatan dalam tujuan pembelajaran yang berisikan unsur-unsur pemahaman, aplikasi, dan analisis, 2) dukungan terhadap isi bahan pelajaran yang bersifat fakta, prinsip, konsep, dan generalisasi agar mudah dipahami, 3) kemudahan cara menggunakan media dan mudah diperoleh, 4) keterampilan guru dalam menggunakan media dalam proses pembelajaran, 5) bermanfaat bagi peserta didik selama proses pembelajaran berlangsung, 6) sesuai dengan taraf berpikir peserta didik, sehingga makna yang terkandung dalam media dapat dipahami oleh peserta didik.

Menurut Arsyad (2017) media pembelajaran merupakan sesuatu yang bersifat menyalurkan pesan dan dapat merangsang pikiran, perasaan dan kemauan audio (peserta didik) sehingga dapat mendorong terjadinya proses belajar membangkitkan keinginan dan minat yang baru, membangkitkan motivasi 


\section{Alfiatun Nur 'Azizah dan Meita Fitrianawati \\ PENGEMBANGAN MEDIA LUDO MATHPADA MATERI PECAHAN SEDERHANA .. WASIS: Jurnal Ilmiah Pendidikan. Volume 1, Nomor 1, hlm. 28-35}

dan rangsangan kegiatan belajar, dan bahkan membawa pengaruh-pengaruh psikologis terhadap peserta didik. Djamarah (2006) menyatakan bahwa media pendidikan sebagai salah satu sumber belajar ikut membantu guru memperkaya wawasan peserta didik. Maka guru yang pandai menggunakan media adalah guru yang bisa manipulasi media sebagai sumber belajar dan sebagai penyalur informasi dan bahan yang disampaikan kepada peserta didik dalam proses pembelajaran.

Berdasarkan hasil wawancara dengan guru kelas III SD Negeri Getas 02, Bawang, Batang, Jawa Tengah pada hari Senin, 2 Mei 2019, guru menjelaskan bahwa peserta didik mengalami kesulitan untuk memahami materimateri pada pelajaran Matematika khususnya dalam memahamkan peserta didik pada materi pecahan sederhana. Hal ini disebabkan karena tidak adanya media pembelajaran ketika proses belajar mengajar berlangsung, guru belum menyajikan media atau alat peraga sebagai jembatan untuk memahamkan peserta didik mengenai materi pecahan sederhana. Pembatasan masalah dalam penelitian ini pada pengembangan media Ludo Math dengan materi pecahan sederhana. Dari masalahmasalah tersebut, tujuan penelitian ini adalah untuk mengetahui langkah-langkah pengembangan media Ludo Math, mengetahui kualitas media Ludo Math, dan mengetahui kelayakan media Ludo Math.

Berdasarkan pemaparan di atas, media Ludo Math yang dikembangkan harus sesuai dengan karakteristik peserta didik kelas bawah. Secara rinci, perkembangan anak usia Sekolah Dasar, dapat dilihat pada perkembangan fisik-motorik, bahasa, emosi, dan sosial. Peserta didik kelas bawah senang bermain dan antusias dengan alat permainan edukatif yang dapat menjadi alternatif untuk menjadikan media pembelajaran yang penting, sehingga guru dapat mengoptimalkan proses pembelajaran khususnya pada materi pecahan sederhana. Permainan digunakan untuk melatih emosi dan membantu anak belajar memahami dan menghargai orang lain.

Media yang akan dikembangkan penulis akan mengadopsi dari permainan Ludo. Materi yang digunakan dalam media Ludo Math adalah materi pecahan sederhana untuk kelas III SD. Penelitian sebelumnya oleh Amkas, dkk (2017), media permainan Ludo sudh dikembangkan yaitu media Ludo Word Game. Persamaan media Ludo Mathdengan media Ludo Word Game adalah sama-sama mengadopsi dari permainan Ludo untuk dijadikan sebuah media pembelajaran.
Sedangkan, perbedaanya yaitu media Ludo Word Game digunakan untuk meningkatkan perbendaharaan kosakata Bahasa Inggris dan media Ludo Math digunakan untuk meningkatkan antusiasme peserta didik dalam mengerjakan soal. Media Ludo Math ini berbahan dasar dari triplek dengan ukuran 51 $\times 51 \times 8 \mathrm{~cm}$. Papan media Ludo Math ini terdapat lubang-lubang dilengkapi dengan penutup bernomor dan arah anak panah untuk alur jalannya pion. Di dalam setiap lubang tersebut berisikan soal-soal yang harus dijawab hingga benar. Semakin pion berjalan jauh, maka akan semakin sulit tingkatan pertanyaannya.

\section{METODE PENELITIAN}

Penelitian ini menggunakan penelitian pengembangan atau Research and Development (R\&D) dari Borg and Gall yang terdapat delapan dari sepuluh langkah pengembangan (Borg and Gall, 1989) yaitu sebagai berikut; 1) research and information collecting (penelitian dan pengumpulan data), 2) planning (perencanaan), 3) develop preliminary form of product (pengembangan produk awal), 4) preliminary field testing (uji coba lapangan awal), 5) main product revision (revisi produk), 6) main field testing (uji lapangan produk utama), 7) operational product revision (revisi produk), and 8) operational field testing ( uji coba lapangan skala besar).

Pada penelitian pengembangan media Ludo Math, uji coba produk dilakukan dalam tiga tahap yaitu, uji coba para ahli oleh ahli media, ahli pembelajaran, dan ahli materi. Kemudian dilanjutkan dengan uji coba produk kelompok kecil yang dilakukan oleh empat peserta didik dan guru kelas III SD Negeri Getas 02. Selanjutnya uji coba pemakaian kelompok besar yang dilakukan oleh 12 peserta didik dan guru kelas III SD Negeri Getas 02. Jumlah keseluruhan peserta didik di kelas III adalah 16 anak.

Instrumen pengumpulan data pada penelitian ini adalah wawancara, observasi, dan kuisioner. Wawancara dilakukan untuk menemukan permasalahan yang harus diteliti secara detail. Wawancara dan observasi dilakukan di awal untuk menemukan masalah yang ada pada pembelajaran matematika khususnya materi pecahan sederhana bagi peserta didik kelas III. Pengumpulan data berupa kuisioner digunakan karena jumlah responden yang cukup banyak. Lembar kuisioner ditujukan kepada para ahli (ahli media, ahli pembelajaran, dan ahli materi) 
untuk menilai kualitas media Ludo Math dan lembar kuisioner ditujukan kepada guru dan peserta didik untuk mengetahui kelayakan media Ludo Math.

Teknik analisis data yang digunakan untuk mengolah hasil data yang didapatkan dari lembar kuisioner (penilaian) adalah menggunakan analisis data kuantitatif dan analisis data kualitatif. Data kuantitatif didapatkan dari penilaian lembar validasi para ahli, guru dan lembar respon peserta didik. Penilaian pada lembar validasi para ahli dan guru berpedoman pada penggunaan skala penilaian 1 sampai 4 (Arikunto, 2013) pada Tabel 1.

Tabel 1. Pedoman Skala Penliaian

\begin{tabular}{lc}
\hline Kategori & Skor Penilaian \\
\hline Sangat Baik & 4 \\
Baik & 3 \\
Cukup Baik & 2 \\
Kurang Baik & 1 \\
\hline
\end{tabular}

Penggunaan skala pada perhitungan kuisioner peserta didik dalam bentuk ceklist menggunakan skala Guttman. Skala pengukuran Guttman memiliki tipe yang tegas, yaitu "Ya-Tidak", "Benar-Salah", "Pernah-Tidak Pernah", "Positif-Negatif", dan lainnya.

Tabel 2. Pedoman Penilaian Skala Guttman

\begin{tabular}{lc}
\hline Kategori & Skor Penilaian \\
\hline Ya & 1 \\
Tidak & 0 \\
\hline
\end{tabular}

Penilaian lembar validasi oleh para ahli dan guru, serta lembar respon peserta didik yang telah dinilai berdasarkan pedoman penilaian yang diadopsi dari Arikunto (2013) dan Skala Guttman, selanjutnya dihitung untuk mendapatkan nilai rata-rata. Kriteria dapat dilihat pada Tabel 3 yaitu sebagai berikut.

Tabel 3. Kriteria Penilaian

\begin{tabular}{cc}
\hline Rentang Nilai & Kategori \\
\hline $81-100$ & Sangat Baik \\
$66-80$ & Baik \\
$51-65$ & Cukup Baik \\
$0-50$ & Kurang Baik \\
\hline
\end{tabular}

Data kualitatif didapatkan dari hasil wawancara pada awal penelitian serta masukan-masukan dari para ahli, guru, dan peserta didik pada lembar validasi dan lembar penilaian. Data yang diperoleh kemudian dianalisis dan dideskripsikan secara kualitatif untuk dijadikan revisi produk yang dikembangkan. Penelitian pengembangan media Ludo Math dinyatakan layak digunakan apabila skor yang didapatkan minimal termasuk dalam kategori "Baik".

\section{HASIL DAN PEMBAHASAN}

Hasil pengembangan yang telah dilakukan oleh penulis dalam penelitian pengembangan media Ludo Math pada materi pecahan sederhana bagi peserta didik kelas III SD dipaparkan dalam langkah-langkah berikut ini.

\section{Research and Information Collection (Penelitian dan Pengumpulan Data)}

Potensi dan masalah yang terdapat pada mata pembelajaran matematika materi Pecahan Sederhana kelas III SD Negeri Getas 02 merupakan hasil pengembangan dari masalah peserta didik yang didapatkan melalui observasi. Masalah yang dialami oleh peserta didik diantaranya adalah belum tersedianya media pembelajaran yang menumbuhkan rasa antusiasme peserta didik dalam menjawab pertanyaan, khususnya pada materi Pecahan Sederhana. Berdasarkan hasil observasi yang dilakukan penulis, guru biasanya hanya memerintahkan peserta didiknya untuk langsung mengerjakan pertanyaan-pertanyaan yang ada pada buku paket atau buku cetak. Hal ini menimbulkan rasa bosan, jenuh, dan kurangnya antusiasme peserta didik dalam mengerjakan pertanyaan tersebut. Dengan demikian, penulis membuat Media Pembelajaran Ludo Math yang dapat menumbuhkan rasa antusiasme peserta didik dan proses pembelajaran terasa lebih menyenangkan serta lebih aktif.

Planning (Perencanaan)

Tahap perencanaan dalam penelitian pengembanan ini meliputi Analisis kurikulum yang dilakukan bertujuan untuk menetapkan $\mathrm{KD}$ dan indikator pembelajaran pada materi pecahan sederhana untuk mengembangkan media Ludo Math. Perencanaan selanjutnya yaitu membuat kisi-kisi instrumen penelitian yang menjadi kriteria untuk menilai kualitas media Ludo Math disesuaikan dengan ahli media, ahli pebelajaran, dan ahli materi. Pembuatan kisi-kisi juga dilakukan untuk mengetahui kelayakan media Ludo Math yaitu dari penilaian guru dan respon peserta didik.

Develop Preliminary form of Product (Pengembangan Produk Awal)

Tahap pertama yang dilakukan pada saat pengembangan produk awal yaitu 


\section{Alfiatun Nur 'Azizah dan Meita Fitrianawati \\ PENGEMBANGAN MEDIA LUDO MATHPADA MATERI PECAHAN SEDERHANA .. WASIS: Jurnal Ilmiah Pendidikan. Volume 1, Nomor 1, hlm. 28-35}

pembuatan lembar penilaian berupa kuisioner untuk para ahli, guru, dan peserta didik berdasarkan kisi-kisi yang telah dibuat. Lembar penilaian validasi para ahli, guru dan peserta didik digunakan mengetahui kualitas dan kelayakan media Ludo Math. Kemudian penulis menyiapkan alat dan bahan untuk pembuatan media tersebut. setelah itu, penulis membuat soal-soal yang berkaitan dengan materi pecahan sederhana sesuai $\mathrm{KD}$ dan indikator yang kemudian disusun dalam sebuah Rencana Pelaksanaan Pembelajaran (RPP).

\section{Preliminary Field Testing (Uji Coba} Lapangan Awal)

Uji coba lapangan awal dilakukan setelah penulis mengembangkan produk awal. Uji coba lapangan awal dilakukan dengan cara memvalidasi media yang dilakukan oleh ahli media, ahli pembelajaran, dan ahli materi. Validasi ahli media Ludo Math ini bertujuan untuk mengetahui hasil penilaian para ahli dan kualitas terhadap media yang dikembangkan penulis. Penilaian dari validasi ahli media diperoleh nilai sebesar 85 dengan kategori "Sangat Baik". Pada penilaian dari validasi ahli pembelajaran diperoleh nilai sebesar 92,5 dengan kategori "Sangat Baik". Penilaian dari validasi ahli materi diperoleh nilai 87,5 dengan kategori "Sangat Baik". Media Ludo Math yang dikembangkan dinyatakan berkualitas dengan proses revisi sesuai dengan masukan-masukan para ahli dan memperoleh nilai rata-rata 88,33 dengan kategori "Sangat Baik".

\section{Main Product Revision (Revisi Produk)}

Tahap ini dilakukan setelah media Ludo Math divalidasi oleh para ahli yang bertujuan untuk mendapatkan media yang berkualitas sebelum dilakukan uji coba lapangan. Revisi produk dilakukan dengan memperbaiki media Ludo Math sesuai dengan penilaian dan masukan-masukan dari para ahli.

\section{Main Field Testing (Uji Lapangan Produk Utama)}

Uji coba produk kelompok kecil dilakukan pada tanggal 5 Desember 2019 dengan jumlah peserta didik 4 anak dan guru kelas III SD Negeri Getas 02. Hasil penilaian guru mendapatkan nilai sebesar 92,5 dengan kategori "Sangat Baik". Sedangkan hasil respon peserta didik mendapatkan nilai sebesar 100 dengan kategori "Sangat Baik". Penilaian guru dan peserta didik mendapatkan nilai rata-rata 96,25 dengan kategori "Sangat Baik".

\section{Operational Product Revision (Revisi Produk)}

Revisi Produk setelah melakukan uji coba produk kelompok kecil, media pembelajaran Ludo Math sudah tidak perlu adanya revisi produk dan sudah mendapatkan hasil yang memuaskan. Sehingga media pembelajaran Ludo Math dapat langsung melanjutkan pada tahap uji coba pemakaian kelompok besar.

\section{Operational Field Testing (Uji Coba Lapangan Skala Besar)}

Uji coba pemakaian kelompok besar dilakukan pada tanggal 11 Desember 2019 dengan jumlah peserta didik 12 anak dan guru kelas III SD Negeri Getas 02. Hasil penilaian guru mendapatkan nilai 97,5 dengan kategori "Sangat Baik". Sedangkan hasil respon peserta didik mendapatkan nilai sebesar 100 dengan kategori "Sangat Baik". Penilaian guru dan peserta didik pada uji coba pemakaian kelompok besar mendapatkan nilai rata-rata 98,75 dengan kategori "Sangat Baik" dan dinyatakan sebagai media yang layak untuk digunakan.

Data uji coba penelitian pengembangan media Ludo Math pada materi pecahan sederhana bagi peserta didik kelas III SD menggunakan data kuntitatif dan data kualitatif. Data kuantitatif digunakan untuk mencari nilai rata-rata dari penilaian validasi ahli media, ahli pembelajaran, dan ahli materi, serta penilaian dari guru dan peserta didik kelas III SD Negeri Getas 02 melalui uji coba produk kelompok kecil dan uji coba pemakaian kelompok besar. Tabel 4 merupakan data kuantitatif hasil dari penilaian validasi para ahli, guru dan peserta didik.

Tabel 4. Data Kuantitatif Hasil Penilaian terhadap Media Ludo Math

\begin{tabular}{llcc}
\hline No. & Penilaian & Nilai & Kategori \\
\hline 1. & Ahli Media & 85 & Sangat Baik \\
2. & Ahli & 92,5 & Sangat Baik \\
& Pembelajaran & & \\
3. & Ahli Materi & 87,5 & Sangat Baik \\
4. & Uji Coba Produk & 96,25 & Sangat Baik \\
& $\quad$ Kelompok Kecil & & \\
5. & Uji Coba & 98,75 & Sangat Baik \\
& Pemakaian & & \\
& Kelompok Besar & & \\
\hline Jumlah & $\mathbf{4 6 0}$ & \\
\hline Rata-Rata & $\mathbf{9 2}$ & Sangat Baik \\
\hline
\end{tabular}

Data kualitatif didapatkan dari hasil wawancara dan pemberian masukan-masukan dari para ahli, guru, dan respon peserta didik. Data kualitatif digunakan untuk mencari 


\section{Alfiatun Nur 'Azizah dan Meita Fitrianawati \\ PENGEMBANGAN MEDIA LUDO MATHPADA MATERI PECAHAN SEDERHANA .. WASIS: Jurnal Ilmiah Pendidikan. Volume 1, Nomor 1, hlm. 28-35}

kualitas dan kelayakan dari media Ludo Math tersebut. Berikut adalah data kualitatif berdasarkan masukan-masukan dari para ahli, guru, dan respon peserta didik terhadap media Ludo Math.

1. Analisis Data Ahli Media

Ahli media memberikan masukan untuk memperbaiki media Ludo Math yaitu mengganti jenis font pada buku petunjuk penggunaan media, menambahkan halaman berisi komponen-komponen media Ludo Math yang disertai dengan gambarnya, dan memperbaiki desain stiker penutup nomor 3 .

2. Analisis Data Ahli Pembelajaran

Ahli pembelajaran memberikan saran untuk memperbaiki komponen dari media Ludo Math yaitu penulis diminta untuk menyesuaikan isi indikator agar lebih sesuai dengan kompetensi dasar dan tujuan pembelajaran. Penulis diharapkan lebih teliti dalam tata cara penulisan, serta diharapkan untuk memperbaiki sintaks pembelajaran.

3. Analisis Data Ahli Materi

Ahli materi memberikan saran untuk memperbaiki media Ludo Math yaitu memperbaiki gambar pecahan sederhana pada soal agar bagian-bagiannya sama besar, mengganti pion agar lebih memiliki karakter, dan oenulis diminta untuk mengganti jenis font dan bold pada buku petunjuk penggunaan dan kunci jawaban media pembelajaran Ludo Math agar tidak melelahkan mata saat dibaca.

4. Analisis Data Uji Coba Produk Kelompok Kecil

Pemberian respon pada uji coba produk kelompok kecil dilakukan oleh empat peserta didik dan guru kelas III SD Negeri Getas 02. Adapun komentar yang diberikan guru dan peserta didik adalah media Ludo Math tampilannya menarik.

5. Analisis Data Uji Coba Pemakaian Kelompok Besar

Pada uji coba pemakaian kelompok besar, tidak ada saran perbaikan dari guru dan peserta didik. Kesimpulan dari seluruh peserta didik adalah media Ludo Math sangat menarik, sehingga peserta didik merasa antusias pada saat mengerjakan soal-soal yang diberikan khususnya pada materi pecahan sederhana.

Produk akhir dari media Ludo Math adalah media yang telah divalidasi oleh ahli media, ahli pembelajaran, dan ahli materi dengan proses revisi. Hasil produk akhir penelitian pengembangan ini adalah media Ludo Math yang termasuk ke dalam jenis media visual. Arsyad (2017: 89) mengemukakan bahwa media pembelajaran berbasis visual merupakan suatu media pembelajaran yang dapat digunakan sebagai alat bantu dalam proses pembelajaran yang hanya dapat diakses digunakan melalui indra penglihatan.

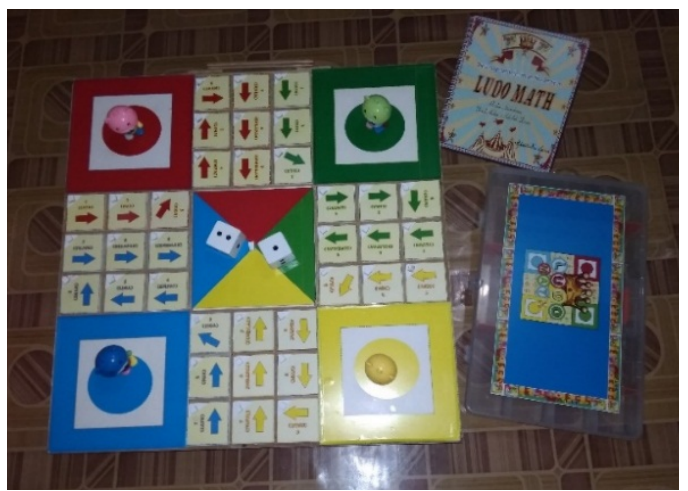

Gambar 1. Media Ludo Math

Media Ludo Math ini memiliki spesifikasi yaitu papan media Ludo Math ini terbuat dari bahan dasar triplek dengan ukuran $51 \mathrm{~cm} \times 51 \mathrm{~cm} \times 8 \mathrm{~cm}$, sehingga menghasilkan sebuah bangun ruang yang berbentuk balok. Pada bagian sisi depan media Ludo Math terdapat lubang-lubang kotak untuk diisi dengan pertanyaan-pertanyaan serta dilengkapi dengan penutupnya. Terdapat dua buah dadu yang berukuran $3 \mathrm{~cm} \times 3 \mathrm{~cm}$ dan empat pion berkarakter boneka dengan tinggi $6 \mathrm{~cm}$ untuk melengkapi media Ludo Math. Media Ludo Math ini dapat digunakan untuk mengatasi keterbatasan media pada pembelajaran matematika kelas III SD Negeri Getas 02.

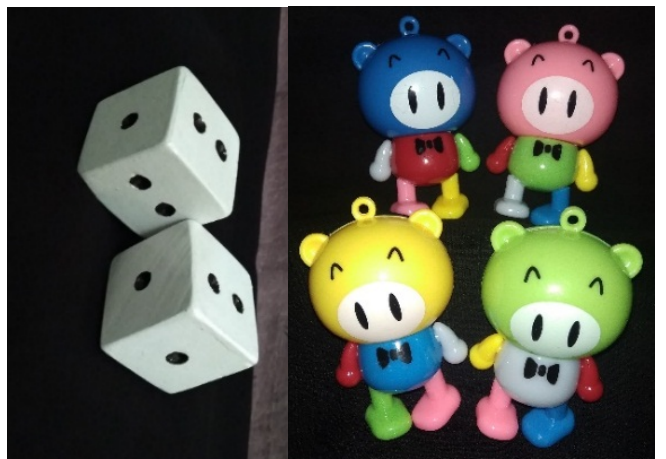

Gambar 2. Dadu dan Pion Media Ludo Math

Keunikan pada media Ludo Math adalah bentuk media dengan lubang-lubang kotak yang didalamnya terdapat gulungan 


\section{Alfiatun Nur 'Azizah dan Meita Fitrianawati \\ PENGEMBANGAN MEDIA LUDO MATHPADA MATERI PECAHAN SEDERHANA .. WASIS: Jurnal Ilmiah Pendidikan. Volume 1, Nomor 1, hlm. 28-35}

pertanyaan yang kemudian lubang tersebut ditutup dengan penutup. Penutup tersebut dilengkapi masing-masing warna (biru, merah, hijau, dan kuning) dengan angka yang berurutan dari 1 sampai 9 yang diikuti dengan anak panah yang menunjukan arah jalannya permainan hingga menuju rumah tengah. Pada setiap lubang kotak yang dilengkapi dengan penutup tersebut berisikan gulungan pertanyaan yang berkaitan dengan materi pecahan sederhana. Pertanyaan-pertanyaan disajikan dalam bentuk permainan Ludo agar peserta didik merasa antusias dan tidak merasa bosan dalam mengerjakan soal.

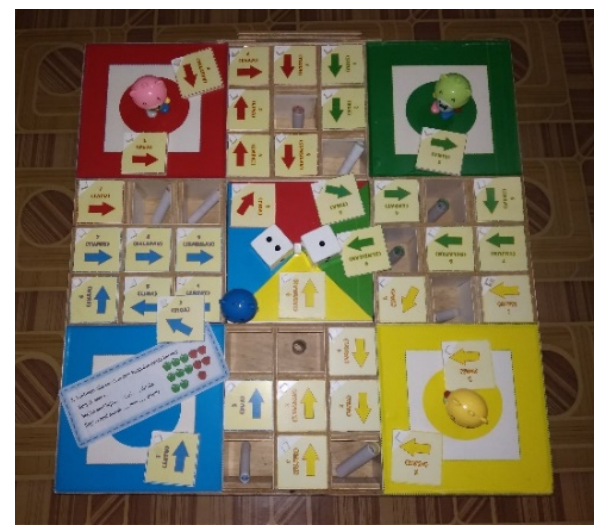

Gambar 3. Isi Media Ludo Math

Media Ludo Math dilengkapi dengan buku Petunjuk Penggunaan dan Kunci Jawaban Media Pembelajaran Ludo Math dengan ukuran $18 \mathrm{~cm} \times 21 \mathrm{~cm}$ dengan tebal 7 lembar (14 halaman). Buku petunjuk ini dicetak menggunakan kertas Ivory 2602 muka dan dijadikan buku dengan finishing menggunakan spiral A4 berwarna putih. Jenis tulisan yang digunakan dalam buku petunjuk penggunaan dan kunci jawaban media pembelajaran Ludo Math ini adalah Comic Sans MS dan Century Gothic. Materi yang disajikan dibatasi hanya pada materi Pecahan Sederhana.

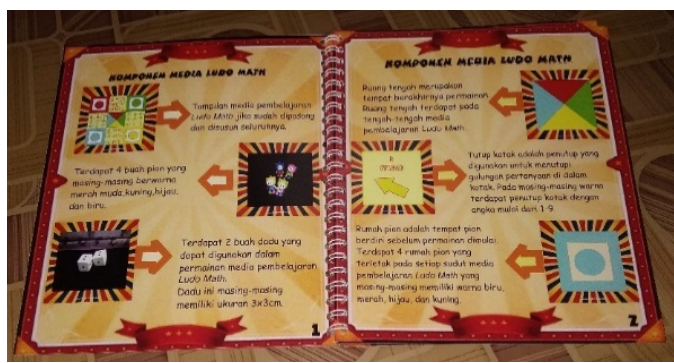

Gambar 4. Alat Pendukung Media berupa Buku Petunjuk
Berdasarkan perhitungan dari hasil uji ahli, uji coba produk kelompok kecil, dan uji coba pemakaian kelompok besar pada media Ludo Math, maka diperoleh hasil rata-rata 92. Apabila dikonversikan ke dalam data kualitatif maka media Ludo Math ini termasuk dalam kategori "Sangat Baik". Jadi dapat disimpulkan bahwa media Ludo Math sudah menjadi produk akhir dengan kualitas dan kelayakan yang sangat baik untuk digunakan dalam proses belajar mengajar pada mata pelajaran Matematika materi Pecahan Sederhana bagi peserta didik kelas III Sekolah Dasar.

\section{SIMPULAN}

Berdasarkan hasil penelitian pengembangan media Ludo Math pada materi pecahan sederhana bagi peserta didik kelas III SD Negeri Getas 02, maka dapat disimpulkan Media Ludo Math dinyatakan berkualitas untuk digunakan sebagai media pembelajaran. Kualitas media Ludo Math dinyatakan, berdasarkan pada penilaian dari para ahli (ahli media, ahli pembelajaran, dan ahli materi). Serta media Ludo Math dinyatakan layak untuk digunakan sebagai media pembelajaran. Kelayakan media Ludo Math dinyatakan, berdasarkan pada respon guru dan peserta didik.

Hasil penilaian menurut ahli media diperoleh nilai 85 dengan kategori "Sangat Baik". Penilaian menurut ahli pembelajaran diperoleh nilai 92,5 dengan kategori "Sangat Baik". Penilaian menurut ahli materi diperoleh nilai 87,5 dengan kategori "Sangat Baik". Hasil Uji Coba Produk Kelompok Kecil, penilaian guru dan respon peserta didik diperoleh nilai rata-rata 96,25 dengan kategori "Sangat Baik". Hasil Uji Coba Pemakaian Kelompok Besar, penilaian guru dan peserta didik diperoleh nilai rata-rata 98,75 dengan kategori "Sangat Baik". Dari seluruh penilaian para ahli, guru, dan peserta didik, media Ludo Math mendapatkan nilai rata-rata 92. Apabila nilai rata-rata dikonversikan ke dalam data kualitatif maka media Ludo Math termasuk dalam kategori "Sangat Baik" dan dinyatakan layak untuk digunakan pada materi Pecahan Sederhana kelas III SD.

\section{DAFTAR PUSTAKA}

Amkas, Sasmita Sindy Intan Mawarni, dkk. 2017. Pengembangan Media Ludo Word Game Siswa Kelas IV SDN Banjar Bali Tahun Pelajaran 2017/2018. Journal Edutech 
Alfiatun Nur 'Azizah dan Meita Fitrianawati

PENGEMBANGAN MEDIA LUDO MATHPADA MATERI PECAHAN SEDERHANA ..

WASIS: Jurnal Ilmiah Pendidikan. Volume 1, Nomor 1, hlm. 28-35

Universitas Pendidikan Ganesha Jurusan Teknologi Pendidikan. 8 (2): $1-11$.

Arsyad, Azhar. 2017. Media Pembelajaran. Jakarta: Raja Grafindo Persada.

Djamarah, Syaiful Bahri dan Aswan Zani. 2006. Strategi Belajar Mengajar. Jakarta: Rineka Cipta.

Fitrianawati, Meita. 2017. Penerapan Problem Based Learning (PBL) dalam Meningkatkan Minat Belajar Matematika pada Mahasiswa PGSD UAD Semester I Th. 2016/2017. JPSD: Jurnal Pendidikan Sekolah Dasar. 3 (2): 13-23.

Gall, Meredith., Joyce P. Gall dan Walter R. Borg. 1989. Educational Research: An Introduction. USA: Pearson Education Inc.
Mardati, Asih. 2016. Pengembangan Modul Matematika dengan Pendekatan Kontekstual pada Materi Bangun Datar untuk Mahasiswa PGSD UAD. JPSD: Jurnal Pendidikan Sekolah Dasar. 3 (1): 1-7.

Permendikbud. 2016. Permendikbud RI Nomor 22 Tahun 2016 Tentang Standar Proses Pendidikan Dasar dan Menengah.

Priatna, Nanang, dan Ricki Yuliardi. 2019. Pembelajaran Matematika untuk Guru SD dan Calon Guru SD. Bandung: Remaja Rosdakarya.

Saputro, Hengkang Bara. 2018. Pengembangan Modul Matematika dengan Pendekatan Kontekstual pada Materi Bangun Ruang Sisi Lengkung untuk Mahasiswa PGSD UAD. JPSD: Jurnal Pendidikan Sekolah Dasar. 5 (1): 52-61.

Sudjana, Nana dan Ahmad Rivai. 2010. Media Pengajaran. Bandung: Sinar Baru Algensindo.

Sundayana, Rostina. 2016. Media dan Alat Peraga dalam Pembelajaran Matematika. Bandung: Alfabeta. 